\title{
PENGARUH KEMAMPUAN, MOTIVASI DAN KOMITMEN ORGANISASI TERHADAP KINERJA KARYAWAN PADA ROS CATERING TAJUR BOGOR
}

\section{INFLUENCE OF ABILITY, COMMITMENT ORGANIZATIONAL AND MOTIVATION AGAINST THE PERFORMANCE EMPLOYEE}

\author{
Rachmat Gunawan ${ }^{1)}$; Sudarijati ${ }^{2)}$ Perismawati Harefa ${ }^{3)}$ \\ Program Studi Manajemen Fakultas Ekonomi Universitas Djuanda Bogor \\ Email : rachmatgun@gmail.com ; sudarjati@unida.ac.id; perismawati00@gmail.com
}

\begin{abstract}
This study aims to analyze the effect of ability, organizational commitment and motivation on the performance of Ros Catering employess Tajur, Bogor. The object of research uses 43 Ros Catering. All Ros Catering employess are the essence of this study. While the research data is analyzed through multiple linear essay analysis techniques using SPSS version 22 software. The results of the research regression show that there is a simultaneous increase in influence from variable, free on the dependent variable this means that the ability variable, organizational commitment and motivation significantly influence employee performance Ros Catering.
\end{abstract}

Keyword: ability, organizational commitment, motivation, Ros Catering employee performance

\begin{abstract}
ABSTRAK
Penelitian ini bertujuan menganalisis pengaruh dari kemampuan, motivasi dan komitmen organisasi bagi kinerja karyawan Ros Catering Tajur Bogor. Objek penelitian menggunakan 43 karyawan Ros Catering Tajur. Semua karyawan Ros Catering menjadi responden dari penelitian ini. Sedangkan data penelitian dengan menggunakan perangkat lunak SPSS versi 22. Penelitian menunjukkan bahwa ada peningkatan pengaruh secara simultan dari variabel bebas pada variabel terikat. Hal ini berarti variabel kemampuan, komitmen organisasi dan motivasi secara signifikan mempengaruhi kinerja karyawan Ros Catering.
\end{abstract}

Kata Kunci: kemampuan, komitmen organisasi, motivasi, kinerja karyawan Ros Catering. 


\section{PENDAHULUAN}

Sumber daya manusia adalah merupakan suatu aset yang sangat penting bagi perusahaan, karena tanpa sumber daya manusia rencana dalam suatu organisasi perusahaan tidak akan berjalan dengan baik, atau tujuan perusahaan tidak akan berjalan optimal. Sumber daya manusia dituntut untuk menjadi unggul dan professional dalam menjalankan pekerjaan yang ditugaskan kepada setiap individu ataupun kelompok.

Sebuah organisasi dalam menjalankan pekerjaan harus memiliki motivasi dan komitmen yang tinggi. Salah satu faktor penting yang digunakan untuk menggerakkan faktor lainnya yaitu sumber daya manusia. Karena pengelolaan SDM dilakukan untuk mendapatkan karyawankaryawan yang handal dan mampu melaksanakan tugasnya secara benar dan bertanggung jawab, sehingga dapat meningkatkan efektivitas organisasi dalam mencapai tujuan.

Kinerja merupakan suatu fungsi dari motivasi dan kemampuan. efektif tidaknya manajemen mengelola suatu organisasi, sehingga kinerja tinggi memberikan indikasi bahwa manajemen bekerja sangat efektif dalam merealisasikan tujuan organisasi. Sebaliknya, kinerja rendah memberi indikasi bahwa manajemen bekerja tidak efektif dalam merealisasikan tujuannya.

Bila seseorang telah memiliki kemampuan kerja yang disyaratkan, hampir dapat dipastikan bahwa orang tersebut akan dapat diandalkan dalam bekerja ( Mulyasa, 2009:38), di samping kemampuan, terdapat faktor-faktor lain dari diri karyawan yang juga mempengaruhi kinerja. Para ahli umumnya memiliki pandangan yang sama bahwa faktor individu yang mempengaruhi kinerja karyawan yaitu komitmen dan motivasi karyawan Mangkunegara (2011:9).

$$
\text { Menurut Luthans (2012:249), }
$$

komitmen organisasi adalah kemauan karyawan untuk tetap menjadi anggota atau bagian dalam organisasi perusahaan itu sendiri, dan keinginan berkarir dalam mengeksplor kemampuan untuk mencapai tujuan perusahaan. Sedangkan motivasi menurut Hamzah (2010:70), adalah kekuatan baik dari dalam maupun dari luar yang mendorong seseorang kelompok atau individu dalam melaksanakan pekerjaan yang telah diberikan.

Dalam pencapaian kinerja yang baik, diperlukan karyawan yang mempunyai daya kerja tinggi untuk memanfaatkan peluang dan antisipasi tantangan persaingan bisinis yang tinggi. Keunggulan kompetitif akan tercapai apabila, pihak manajemen dapat mengelola inti dari aktivitas perusahaan dengan mendorong SDM. Permasalahan kinerja karyawan perusahaan Ros Catering yang mengalami penurunan dan tidak tercapainya target yang ditetapkan perusahaan disebabkan oleh adanya persaingan dalam bisnis kuliner. Berikut data penjualan dan pesanan Ros Catering dari tahun 2016 - 2018 .

Tabel 1.1 Penjualan Ros Catering Tahun 2016-2018

\begin{tabular}{cccc}
\hline Tahun & $\begin{array}{c}\text { Target penjualan } \\
(\mathbf{R p})\end{array}$ & $\begin{array}{c}\text { Realisasi } \\
(\mathbf{R p})\end{array}$ & $\begin{array}{c}\text { Presentase Pencapian } \\
(\boldsymbol{\%})\end{array}$ \\
\hline 2016 & 24.000 .000 .000 & 18.000 .000 .000 & 75 \\
2017 & 18.000 .000 .000 & 12.000 .000 .000 & 67 \\
2018 & 18.000 .000 .000 & 9.600 .000 .000 & 50 \\
\hline \multicolumn{2}{c}{ Rata-rata } & & 64 \\
\hline
\end{tabular}

Sumber : Data Perusahaan Ros Catering

Berdasarkan Tabel 1.1 dan 1.2 target penjualan rata-rata tercapai $64 \%$ selama tahun 2016-2018, dapat dilihat kinerja Ros Catering belum dicapai secara optimal.
Menurut informasi HRD Ros Catering (Pak Hendra) penurunan tersebut disebabkan oleh persaingan yang semakin tinggi, persaingan dalam bidang kuliner. 
Tabel 1.2 Pesaing Ros Catering

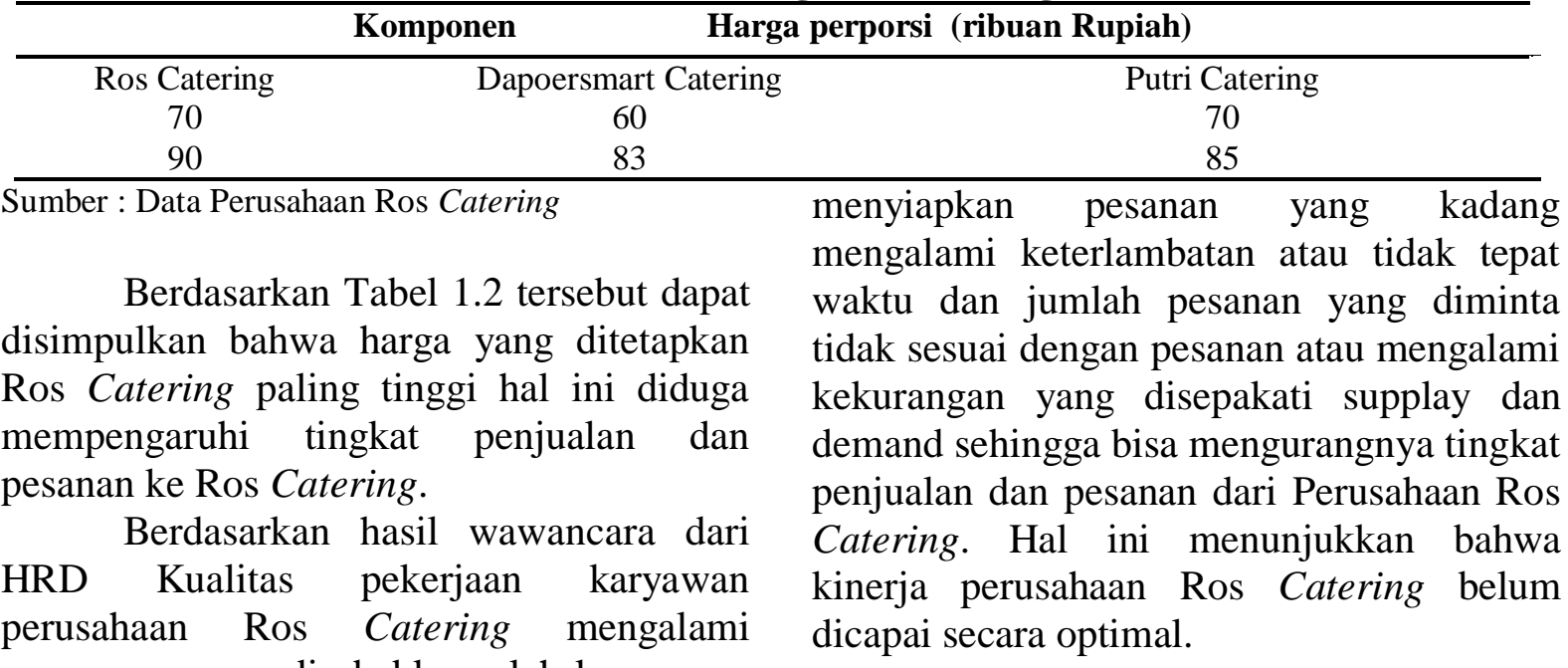

penurunan yang disebabkan oleh kurangnya kerapihan dan ketelitian karyawan dalam melaksanakan tugas terutama kecepatan

\section{MATERI DAN METODE}

\section{Kemampuan}

Menurut Sri Hadiati (2014:34). mendefinisikan kemampuan lebih pada

\section{Komitmen organisasi}

Menurut Luthans (2012:249), komitmen organisasi ialah kemauan karyawan untuk tetap menjadi anggota atau bagian dalam organisasi perusahaan itu sendiri, dan keinginan berkarir dalam mengeksplorisasi kemampuan untuk mencapai tujuan perusahaan.

\section{Motivasi}

Menurut Hamzah (2010:249), ialah kekuatan baik dari dalam maupun dari luar yang mendorong seseorang kelompok atau individu dalam melaksanakan pekerjaan yang telah diberikan.

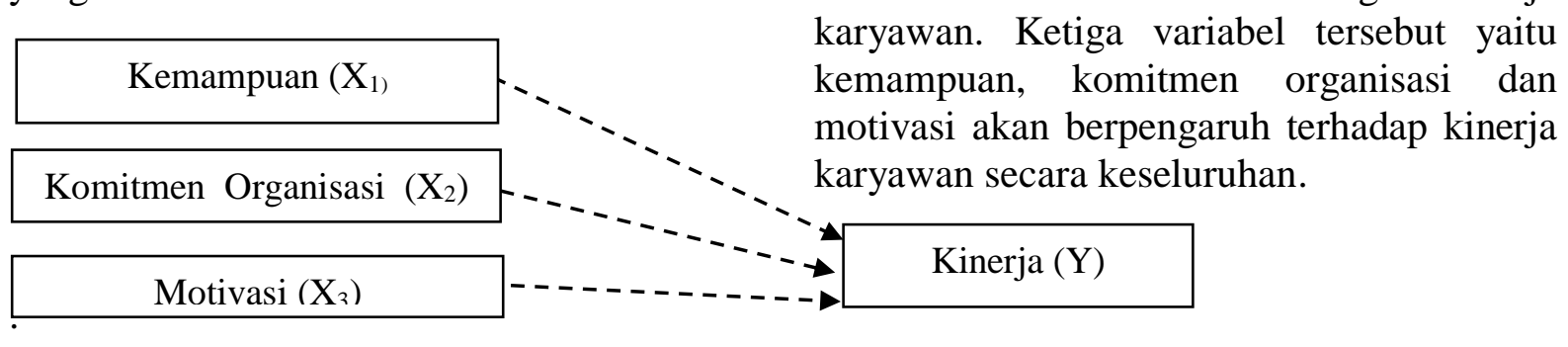

Gambar 1. Kerangka Pemikiran

$$
\begin{aligned}
& \text { Di mana : } \\
& \mathrm{X}_{1} \quad=\text { Kemampuan, }
\end{aligned}
$$

keefektifan orang tersebut dalam melakukan segala macam pekerjaan. yang artinya kemampuan merupakan dasar dari seseorang tersebut melakukan sebuah pekerjaan secara efektif dan efisien.

\section{Kinerja}

Kinerja ialah hasil dari proses pekerjaan secara terencana pada waktu dan tempat tertentu. Sedangkan menurut Bangun (2012:231), kinerja ialah ukuran kinerja dilihat dari sisi jumlah dan mutu tertentu, sesuai standar organisasi perusahaan.

\section{Kerangka Pemikiran}

Faktor kemampuan, komitmen dan motivasi berkaitan dengan beban kerja dan tuntutan kerja yang dapat menimbulkan karyawan untuk terus menggali kemampuan yang dimiliki. Kemudian motivasi akan mampu menjadi semangat dalam memacu dan menumbuhkan semangat kerja karyawan. Ketiga variabel tersebut yaitu kemampuan, komitmen organisasi dan motivasi akan berpengaruh terhadap kinerja 
$\mathrm{X}_{2} \quad=$ komitmen organisasi,

$\mathrm{X}_{3} \quad=$ Motivasi,

$\mathrm{Y} \quad=$ Kinerja Karyawan

$\longrightarrow$ =Pengaruh Secara Simultan

Berdasarkan latar belakang masalah, maka yang menjadi rumusan masalah dalam penelitian ini adalah:

1) variabel kemampuan, motivasi secara simultan berpengaruh terhadap kinerja karyawan perusahaan Ros Catering Tajur.

2) kemampuan berpengaruh terhadap kinerja karyawan perusahaan Ros Catering Tajur.

3) motivasi berpengaruh terhadap kinerja karyawan perusahaan Ros Catering Tajur.

\section{Populasi dan Sampel}

Populasi adalah keseluruhan dari subyek penelitian yang memiliki sifat yang sama walaupun presentase kesamaan itu sedikit, atau dengan kata lain seluruh individu yang akan dijadikan sebagai obyek penelitian kepada selauruh karyawan Perusahaan Ros Catering Tajur Bogor yang berjumlah 43 karyawan.

\section{Desain Penelitian}

Penelitian ini termasuk penelitian survey yang dimaksudkan menggambarkan hubungan - hubungan yang terjadi diantara variabel - variabel penelitian, sedangkan menurut Husein (2010:106) merupakan proses yang dilakukan dalam perencanaan dan pelaksanaan penelitian.

\section{Metode Pengumpulan Data}

Pengambilan data secara tertutup. Pertanyaan atau pernyataan tersusun dalam angket berbentuk pilihan berganda dimana responden tinggal memilih alternatif jawaban yang tersedia. Setiap alternatif jawaban telah disesuaikan dengan pokok permasalahan dan tujuan penelitian. Alternatif pengukuran skor 5 untuk respon sangat setuju, skor 4 untuk respon setuju, skor 3 untuk respon kurang setuju, skor 2 untuk respon tidak setuju dan skor1 untuk respon sangat tidak setuju.

Tabel 3. Operasionalisasi Variabel

\begin{tabular}{|c|c|c|}
\hline Variabel & Konsep Variabel & Indikator \\
\hline Kemampuan $\left(\mathrm{X}_{1}\right)$ & $\begin{array}{l}\text { Kemampuan (ability) merupakan kapasitas individu untuk } \\
\text { melaksanakan berbagai tugas dalam pekerjaan tertentu. } \\
\text { Paramita R.(2016:38) }\end{array}$ & $\begin{array}{l}\text { - Pengetahuan } \\
\text { - Pelatihan } \\
\text { - Pengalaman } \\
\text { - Ketrampilan } \\
\text { - Kesanggupan kerja }\end{array}$ \\
\hline $\begin{array}{l}\text { Komitmen } \\
\text { Organisasi }\left(\mathrm{X}_{2}\right)\end{array}$ & $\begin{array}{l}\text { Komitmen organisasi adalah suatu konstruk psikologis } \\
\text { yang merupakan karakteristik hubungan anggota organisasi } \\
\text { dengan organisasinya, dan memiliki implikasi terhadap } \\
\text { keputusan individu untuk melanjutkan keanggotaan dalam } \\
\text { berorganisasi (Allen dan Meyer 2013:182) }\end{array}$ & $\begin{array}{l}\text { - Komitmen afektif } \\
\text { - Komitmen } \\
\text { berkelanjutan } \\
\text { - Komitmen } \\
\text { - normatif }\end{array}$ \\
\hline Motivasi $\left(\mathrm{X}_{3}\right)$ & $\begin{array}{l}\text { Motivasi sebagai suatu dorongan untuk meningkatkan } \\
\text { usaha dalam mencapai tujuan- tujuan organisasi, dalam } \\
\text { batasan-batasan kemampuan untuk memberikan kepuasan } \\
\text { atas kebutuhan seseorang Mangkunegara (2011:75) }\end{array}$ & $\begin{array}{l}\text { - Motif } \\
\text { - Harapan } \\
\text { - Insentif }\end{array}$ \\
\hline $\begin{array}{c}\text { Kinerja Karyawan } \\
(\mathrm{Y})\end{array}$ & $\begin{array}{l}\text { Kinerja adalah hasil kerja yang dicapai seseorang } \\
\text { berdasarkan persyaratan-persyaratan pekerjaan menurut } \\
\text { Anwar Prabu Mangkunegara }(2013: 75)\end{array}$ & $\begin{array}{l}\text { - Kualitas } \\
\text { - Kuantitas } \\
\text { - Pelaksanaan tugas } \\
\text { - Tanggung jawab }\end{array}$ \\
\hline
\end{tabular}




\section{Analisis Data}

Analisis data selain menggunakan analisis deskriptif juga menggunakan analisis verifikatif. Analisis deskriptif digunakan untuk menggambarkan klasifikasi data, sementara analisis verifikatif digunakan untuk mendukung hipotesis yang menggunakan analisis regresi.

\section{Analisis Regresi Berganda}

Analisis regresi linear berganda adalah untuk meramalkan bagaimana keadaan (naik turunnya) variabel dependen, bila dua atau lebih variabel independen $\left(\mathrm{X}_{1}\right.$, $\mathrm{X}_{2}$ dan $\mathrm{X}_{3}$ ) sebagai faktor prediktor dimanipulasi atau dinaik turunkan nilainya. Menurut Sugiono (2013:284) rumus analisis regresi berganda adalah sebagai berikut:

$$
Y=a+b_{1} X_{1}+b_{2} X_{2}+b_{3} X_{3}+\varepsilon
$$

Dimana :

$$
\begin{aligned}
\mathrm{Y}= & \text { Kinerja karyawan } \\
\mathrm{X}_{1}= & \text { Kemampuan } \\
\mathrm{X}_{2}= & \text { Komitmen Organisasi } \\
\mathrm{X}_{3}= & \text { Motivasi } \\
\mathrm{b}_{1}= & \text { Koefisien regresi variabel } \\
& \text { kemampuan } \\
\mathrm{b}_{2}= & \text { Koefisien regresi variabel } \\
& \text { komitmen organisasi } \\
\mathrm{b}_{3}= & \text { Koefisien regresi variabel motivasi }
\end{aligned}
$$

Gambar 2 menjelaskan bahwa pengujian hipotesis penelitian ini menggunakan uji satu pihak. Pada variabel Kemampuan, Komitmen organisasi, dan Motivasi, menggunakan uji pihak kanan karena sudah dibuktikan oleh penelitian terdahulu

\section{PEMBAHASAN HASIL PENELITIAN}

Perusahaan Ros Catering bergerak dalam bidang usaha jasa boga atau catering service untuk penanganan kebutuhan pesta, khususnya dalam penyediaan hidangan pesta $\varepsilon=$ Standar error

\section{Analisis Korelasi Berganda}

Untuk mengetahui bagaimana hubungan antara kemampuan, komitmen organisasi dan motivasi terhadap kinerja karyawan perusahaan Ros Catering.

\section{Analisis Koefesien Determinasi}

Koefisien determinasi merupakan alat untuk mengukur seberapa jauh kemampuan model dalam menerangkan variasi variabel dependen. Nilai koefisien determinasi adalah antara nol atau satu. Rumus koefisien determinasi menurut Ghozali (2012 : 97) adalah sebagai berikut:

$$
\mathrm{KD}=\mathrm{r}^{2} \times 100 \%
$$

Di mana:

$$
\begin{aligned}
\mathrm{KD} & =\text { Koefisien Determinasi } \\
\mathrm{r} & =\text { Koefisien Kolerasi }
\end{aligned}
$$

\section{Uji Hipotesis}

Dalam penelitian ini akan diuji hipotesis secara simultan (uji F) dan pengujian secara parsial (uji t). adapun ujisatu pihak dapat dilihat pada Gambar 2 berikut ini :

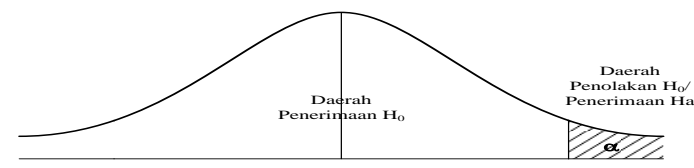

\section{Gambar 2 Uji Satu Pihak}

Sumber : Sugiyono (2016:180)

sehingga pengujian hipotesisnya bertujuan Untuk mengetahui seberapa besar pengaruh variabel independen tersebut terhadap variabel dependen.

pernikahan, khinatan, Ulang tahun, rapat, seminar, pelatihan, piknik dan konsumsi karyawan perusahaan dengan berbagai jenis makanan, baik makanan international dan lokal (makanan khas daerah). 
Tabel 4 Rekapitulasi Tanggapan Karyawan Terhadap Variabel Kemampuan

\begin{tabular}{|c|c|c|c|}
\hline No & Pernyataan & Jawaban & Kriteria \\
\hline 1 & Pengetahuan karyawan melayani pesanan cukup baik & 3,84 & Baik \\
\hline 2 & Menyiapkan makanan sesuai pesanan & 3,93 & Baik \\
\hline 3 & Pelatihan dapat meningkatkan ketrampilan & 3,84 & Baik \\
\hline 4 & $\begin{array}{l}\text { Pelatihan meningkatkan kemampuan untuk menyelesaikan } \\
\text { pekerjaan }\end{array}$ & 3,67 & Baik \\
\hline 5 & $\begin{array}{l}\text { Pengalaman kerja membantu menyelesaikan tugas dengan } \\
\text { cepat }\end{array}$ & 3,58 & Baik \\
\hline 6 & Pengalaman mampu meningkatkan kinerja perusahaan & 3,74 & Baik \\
\hline 7 & Ketrampilan mendukung meningkatkan kualitas pekerjaan & 3,70 & Baik \\
\hline 8 & $\begin{array}{l}\text { Ketrampilan membantu menyelesaikan tugas yang } \\
\text { dibebankan dengan baik }\end{array}$ & 3,81 & Baik \\
\hline 9 & $\begin{array}{l}\text { Kaya bersedia bekerja lembur bila diperlukan untuk } \\
\text { menyelesaikan pekerjaan yang diberikan }\end{array}$ & 3,93 & Baik \\
\hline \multirow[t]{2}{*}{10} & menyelesaikan tugas secara cepat dan tepat & 4,07 & Baik \\
\hline & Nilai Rata-rata & 3,81 & Baik \\
\hline
\end{tabular}

Sumber: Data Diolah, 2019

Berdasarkan Tabel 4 tersebut dapat diketahui bahwa nilai rata-rata tanggapan sebesar 3,81 yang termasuk dalam kategori karyawan untuk variabel kemam.

Tabel 5 Rekapitulasi Tanggapan Karyawan atas Variabel Komitmen Organisasi

\begin{tabular}{clcc}
\hline No & \multicolumn{1}{c}{ Pernyataan } & Jawaban & Kriteria \\
\hline 1 & Bangga dapat berkarir diperusahaan & 3,95 & Baik \\
2 & Percaya terhadap organisasi & 3,74 & Baik \\
3 & Mengabdi pada organisasi karena memiliki keterikatan & 3,67 & Baik \\
4 & $\begin{array}{l}\text { Mencintai organisasi dengan tulus karena adanya kesadaran } \\
\text { dalam individu }\end{array}$ & 3,74 & Baik \\
5 & Bertahan diorganisasi karena komitmen yang tinggi & 3,72 & Baik \\
6 & Bersedia mengorbankan kepentingan pribadi demi & 3,88 & Baik \\
& organisasi & 3,81 & Baik \\
7 & Memiliki keterikatan pada pekerjaan & 3,72 & Baik \\
8 & Loyalitas untuk bertahan diperusahaan cukup tinggi & 3,81 & Baik \\
9 & Kesetiaan terhadap organisasi merupakan suatu keharusan & 3,74 & Baik \\
\hline 10 & Bahagia bekerja pada organisasi yang baik dan mendukung & 3,77 & Baik \\
\hline
\end{tabular}
Sumber: Data Diolah, 2019

Berdasarkan tabel rekapitulasi

organisasi memiliki nilai rata-rata sebesar tersebut, dapat diketahui bahwa jawaban 3,77 yang termasuk karyawan untuk variabel komitmen
dalam
kategori
baik

Tabel 6 Rekapitulasi Tanggapan Karyawan Terhadap Variabel Motivasi

\begin{tabular}{clcc}
\hline No & \multicolumn{1}{c}{ Pernyataan } & Jawaban & Kriteria \\
\hline 1 & upah yang adil dan layak & 4,33 & Sangat Baik \\
2 & Pengakuan sebagai individu & 4,35 & Sangat Baik \\
3 & Pengakuan atas prestasi & 4,35 & Sangat Baik \\
4 & Kesempatan untuk maju & 4,26 & Sangat Baik \\
5 & Tempat kerja yang baik & 4,33 & Sangat Baik \\
6 & Kondisi kerja yang baik & 4,51 & Sangat Baik \\
7 & Penghargaan penuh atas penyelesaian pekerjaan & 4,44 & Sangat Baik \\
8 & Perhatian pimpinan terhadap karyawan & 4,58 & Sangat Baik \\
\hline
\end{tabular}




\begin{tabular}{clcc}
\hline 9 & Pemahaman yang simpatik atas persoalan pribadi & 4,33 & Sangat Baik \\
10 & Jaminan pekerjaan & 4,40 & Sangat Baik \\
11 & Gaji dan upah & 4,37 & Sangat Baik \\
12 & Tunjangan & 4.30 & Sangat Baik \\
13 & Promosi jabatan & 4,42 & Sangat Baik \\
\hline & Nilai Rata-rata & 4,38 & Sangat Baik \\
\hline
\end{tabular}

Sumber: Data Diolah, 2019

Berdasarkan Tabel 4.43 hasil dari

karyawan terhadap variabel motivasi adalah rekapitulasi diperoleh rata-rata penilaian sebesar 4,38 yang termasuk dalam kategori sangat baik.

Tabel 7 Rekapitulasi Tanggapan Karyawan Terhadap Variabel Kinerja

\begin{tabular}{llcc}
\hline No & \multicolumn{1}{c}{ Pernyataan } & Jawaban & Kriteria \\
\hline 1 & Ketepatan dan ketelitian & 3,98 & Tinggi \\
2 & Kebersihan hasil tugas & 3,95 & Tinggi \\
3 & Kesempurnaan tugas & 3,70 & Tinggi \\
4 & Kecepatan & 3,88 & Tinggi \\
5 & Jumlah yang dihasilkan & 3,86 & Tinggi \\
6 & Jumlah unit yang diselesaikan & 3,88 & Tinggi \\
7 & Kehandalan dalam menyelesaikan tugas & 3,98 & Tinggi \\
8 & Pengetahuan tentang pekerjaan & 3,86 & Tinggi \\
9 & Kesadaran akan kewajiban melaksanakan pekerjaan & 3,98 & Tinggi \\
10 & Kesanggupan menyelesaikan tugas & 3,95 & Tinggi \\
11 & Memikul resiko atas keputusan yang diambil & 3,84 & Tinggi \\
\hline & Nilai Rata-rata & 3,90 & Tinggi \\
\hline
\end{tabular}

Sumber: Data Diolah, 2019

Tabel 4.6 Rekapitulasi Karakteristik Karyawan

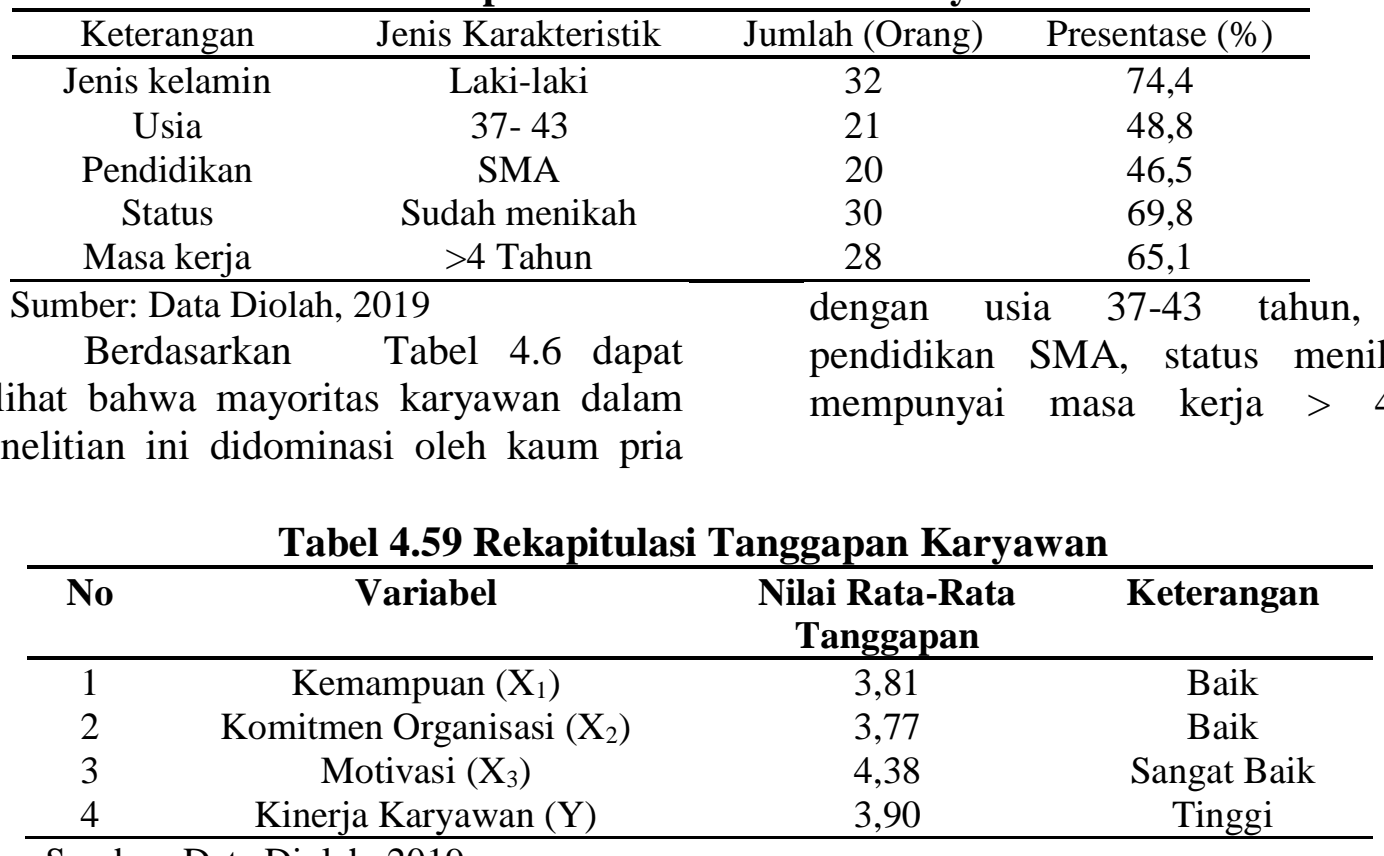

Sumber: Data Diolah, 2019

\section{Hasil Analisis Regresi}

\section{Tabel 4.60 koefisien Regresi dan uji signifikasi coefficient} Coefficients $^{a}$ 


\begin{tabular}{|c|c|c|c|c|c|}
\hline \multirow[b]{2}{*}{ Model } & \multicolumn{2}{|c|}{$\begin{array}{l}\text { Unstandardized } \\
\text { Coefficients }\end{array}$} & $\begin{array}{l}\text { Standardized } \\
\text { Coefficients }\end{array}$ & \multirow[b]{2}{*}{$\mathrm{t}$} & \multirow[b]{2}{*}{ Sig. } \\
\hline & $\mathrm{B}$ & Std. Error & Beta & & \\
\hline (Constant) & 183 & 5,666 & & ,032 & ,974 \\
\hline KEMAMPUAN & 465 & 111 & ,501 & 4,196 & ,000 \\
\hline KOMITMEN ORGANISASI & 262 & 133 & ,23 & 1,966 & ,056 \\
\hline MOTIVASI & ,264 & 106 & ,256 & 2,487 &, 017 \\
\hline
\end{tabular}

a. Dependent Variable: Kinerja

Sumber: data diolah, 2019

Berdasarkan tabel tersebut diperoleh suatu persamaan regresi dengan model $Y=\mathbf{0 , 1 8 3}+\mathbf{0 , 4 6 5} X_{1}+\mathbf{0 , 2 6 2} X_{2}+\mathbf{0 , 2 6 4} X_{3}+\mathbf{e}$ taksiran sebagai berikut:

\section{Hasil Analisis Korelasi Berganda}

Tabel 4.61 Pengujian Koefisien Determinasi Model Summaryb

\begin{tabular}{|l|r|r|r|r|}
\hline Model & $\mathrm{R}$ & R Square & Adjusted R Square & Std. Error of the Estimate \\
\hline 1 &, $822^{\mathrm{a}}$ &, 676 &, 651 & 2,661 \\
\hline
\end{tabular}

a. Predictors: (Constant), MOTIVASI, KOMITMEN ORGANISASI, KEMAMPUAN

Sumber: Data Diolah, 2019

Adapun hubungan antara kemampuan, komitmen organisasi ,motivasi bagi kinerja karyawan menunjukkan angka 0,822 yang berarti memiliki hubungan yang sangat kuat.

\section{Analisis Koefisien Determinasi}

Berdasarkan Tabel 4.61 tersebut juga dapat diketahui bahwa besarnya $R$ Square $67,6 \%$. Hal ini menunjukkan bahwa presentase sumbangan pengaruh variabel kemampuan $\left(\mathrm{X}_{1}\right)$, motivasi $\left(\mathrm{X}_{3}\right)$, komitmen organisasi $\left(\mathrm{X}_{2}\right)$ bagi kinerja karyawan (Y) sebesar $67,6 \%$. sisanya dipengaruhi oleh variabel lain sebesar $32,4 \%$ seperti kepuasan kerja, kepemimpinan, dan budaya kerja.
Pengujian Model Regresi Secara Simultan (Uji-F)

Untuk mengetahui hubungan secara simultan variabel kemampuan $\left(\mathrm{X}_{1}\right)$, komitmen organisasi $\left(\mathrm{X}_{2}\right)$ dan motivasi $\left(\mathrm{X}_{3}\right) . \mathrm{F}$ hasil penelitian sebesar 0,000 sedangkan $\alpha$ (alpha) sebesar 0,05 sehingga $0,000<0,05$, hal ini berarti bahwa variabel bebas mempunyai hubungan dengan variabel terikat, sehingga hipotesis pertama yang diajukan diterima Uji $\mathrm{F}$ untuk melihat pengaruh variabel bebas (independent) yaitu kemampuan $\left(\mathrm{X}_{1}\right)$, komitmen organisasi $\left(\mathrm{X}_{2}\right)$ dan motivasi $\left(\mathrm{X}_{3}\right)$ memiliki pengaruh dengan variabel terikat (dependent) kinerja karyawan (Y).

Tabel 4.62 Hasil Uji F

ANOVA

\begin{tabular}{|l|r|r|r|r|c|}
\hline Model & $\begin{array}{c}\text { Sum of } \\
\text { Squares }\end{array}$ & \multicolumn{1}{|c|}{ df } & \multicolumn{1}{c|}{$\begin{array}{c}\text { Mean } \\
\text { Square }\end{array}$} & F & Sig. \\
\hline Regression & 575,032 & 3 & 191,677 & 27,072 &, $000^{\mathrm{b}}$ \\
Residual & 276,131 & 39 & 7,080 & & \\
Total & 851,163 & 42 & & & \\
\hline
\end{tabular}

a. Dependent Variable: KINERJA

b. Predictors: (Constant), motivasi, komitmen organisasi, kemampuan

Sumber: Data Diolah, 2019

Berdasarkan nilai $\mathrm{F}$ hitung pada tabel tersebut diketahui $F_{\text {hitung sebesar 27,072 dan }}$ nilai $\mathrm{F}_{\text {tabel }}$ untuk $\alpha=50 \%$ kebebasan derajat $\mathrm{V}_{1}=4-1=3$ dan $\mathrm{V}_{2}=43-3-1=39$ sebesar
2,84, sehingga $F_{\text {hitung }}>F_{\text {tabel, }}$, maka dapat disimpulkan bahwa dari hasil uji $\mathrm{F}$ tersebut terbukti bahwa hipotesis pertama yang mengungkapkan bahwa variabel 
kemampuan (X1) dan motivasi (X2) secara simultan berpengaruh positif untuk kinerja karyawan (Y) atau diterima.

\section{Pengujian Model Regresi Secara Parsial (Uji-t)}

Uji $\mathrm{t}$ dilakukan dengan membandingkan $t_{\text {hitung dan }} t_{\text {tabel. }}$. Jika thitung lebih besar dari $t_{\text {tabel }}\left(t_{\text {hitung }}>t_{\text {tabel }}\right)$ maka menunjukkan bahwa variabel $\mathrm{X}_{1}, \mathrm{X}_{2}$, dan $\mathrm{X}_{3}$ satu persatu memiliki hubungan dengan Y. Secara lebih jelas dikemukakan pada Tabel 4.63 berikut ini:

Tabel 4.63 Hasil Uji -t Coefficients $^{\mathrm{a}}$

\begin{tabular}{|c|c|c|c|c|c|}
\hline \multirow[b]{2}{*}{ Model } & \multicolumn{2}{|c|}{$\begin{array}{c}\text { Unstandardized } \\
\text { Coefficients }\end{array}$} & \multirow{2}{*}{$\begin{array}{c}\begin{array}{c}\text { Standardized } \\
\text { Coefficients }\end{array} \\
\text { Beta }\end{array}$} & \multirow[b]{2}{*}{$\mathrm{t}$} & \multirow[b]{2}{*}{ Sig. } \\
\hline & $\mathrm{B}$ & Std. Error & & & \\
\hline (Constant) &, 183 & 5,666 & &, 032 & ,974 \\
\hline KEMAMPUAN & ,465 &, 111 &, 501 & 4,196 &, 000 \\
\hline KOMITMEN ORGANISASI & ,262 & , 133 & ,234 & 1,966 & ,056 \\
\hline MOTIVASI & ,264 & , 106 & ,256 & 2,487 &, 017 \\
\hline
\end{tabular}

Sumber Data Diolah, 2019

Berdasarkan Tabel 4.60 tersebut, dapat dilihat bahwa thitung untuk kemampuan sebesar 4,196 dan nilai $\mathrm{t}_{\text {tabel }} \alpha=50 \%$ kebebasan derajat k 43-3-1=39 sebesar 2,384 berarti $t_{\text {hitung }}>t_{\text {tabel }}(4,196>2,384)$.

\section{KESIMPULAN DAN SARAN}

\section{Simpulan}

1. Kondisi kemampuan secara rata-rata berada pada kategori baik, komitmen organisasi rata-rata berada pada kategori baik, motivasi rata-rata berada pada kategori sangat tinggi dan kinerja karyawan pada Perusahaan Ros Catering Tajur Bogor secara rata-rata menunjukkan baik.

2. Variabel Motivasi berpengaruh signifikan terhadap terhadap Kinerja Karyawan Ros Catering. Hal ini

\subsection{Saran}

1. Untuk meningkatkan kinerja karyawan pada Perusahaan Ros Catering, maka sebaiknya perusahaan mengadakan pelatihan yang intensif bagi karyawan dan juga memiliki pengalaman dalam bidang pekerjaan yang dibutuhkan, seperti kemampuan untuk menyelesaikan pekerjaan dengan standar yang ditentukan perusahaan.

2. Untuk komitmen organisasi pengabdian karyawan pada perusahaan harus
Kesimpulannya $\mathrm{Ha}$ diterima dan $\mathrm{H}_{0}$ ditolak, artinya kemampuan $\left(\mathrm{X}_{1}\right)$ berpengaruh dengan variabel dependen.

memiliki makna bahwa semakin tinggi motivasi kerja yang diberikan perusahaan kepada karyawan maka kinerjanya memuaskan. Motivasi berupa gaji masih merupakan daya tarik utama yang menyebabkan seseorang melakukan sesuatu karena adanya imbalan yang akan memuaskan kebutuhannya. Pertimbangan berkesinambungan untuk kepuasan yang akan diperoleh, jika usaha ditingkatkan menjadi suatu pelaksanaan, jika pelaksanaan itu berhasil dan jika imbalan yang dijanjikan diterima

ditingkatkan karena komitmen merupakan suatu keputusan atau perjanjian seseorang dengan dirinya sendiri untuk melakukan atau tidak melakukan, berhenti atau meneruskan suatu perbuatan atau kegiatan dan meningkatkan rasa keterikatannya dengan karyawan, serta terhadap organisasinya.

3. Untuk kinerja karyawan sebaiknya perusahaan dalam meningkatkan kinerja karyawan tidak hanya memperhatikan pada pencapaian target dan ketepatan 
waktu saja, akan tetapi dari segi kualitas pekerjaanya agar tidak hanya memuaskan pihak manajemen saja tetapi memuaskan konsumen juga. Untuk itu sebaiknya karyawan diberi pedoman dalam bekerja sebagai acuan untuk melaksanakan pekerjaan agar

\section{UCAPAN TERIMA KASIH}

Ucapan terima kasih kepada perusahaan Ros Catering yang sudah bersedia menjawab dan mengisi kuisioner penelitian ini.

\section{DAFTAR PUSTAKA}

Allen and Meyer. 2013. The Measurement and Antecedents of Affective, Contintinuance and

NormativeCommitment to Organitazion. Jakarta: PT Elex Media Komputindo.

A.M, Sardiman. 2007. Interaksi \& Motivasi

Belajar Mengajar. Jakarta : PT Grafindo Persada

Anwar Prabu Mangkunegara. 2015. Sumber Daya Manusia Perusahaan. Cetakan kedua belas. Remaja Rosdakarya:Bandung.

Bangun, Wilson, 2012 "Manajemen Sumber Daya Manusia", Jakarta Erlangga hasil yang dicapai memenuhi standar dan berkualitas tingggi.

4. Untuk penelitian selanjutnya dapat ditambahkan variabel-variabel yang berhubungan bagi kinerja karyawan selain kemampuan, diantaranya lingkungan kerja, beban kerja, kepemimpinan dan lain sebagainya.

Erline Kristine. 2017. Pengaruh Komitmen Organisasi Kepuasan Kerja dan Motivasi Terhadap Kinerja Kerja Pegawai Alih Daya (Outsourcing) di PT. Mitra Karya Jaya Sentosa. Jurnal EKSEKUTIF Volume 14 No. 2 Desember 2017 hal 384-401

Hamzah. 2010. Teori Motivasi dan Pengukurannya, Jakarta : Pt Bumi Aksara

Husein, Umar, 2010, Riset pemasaran dan bisnis, Gramedia pustaka utama, Jakarta.

Luthans, Fred. 2012. "Perilaku Organisasi". Yogyakarta: Penerbit Andi

Raharjo, Paramita dan Warso.2016. Pengaruh Pengalaman dan Pelatihan Kemampuan Kerja, Terhadap Produktivitas Kerja Karywan Dengan Komptensi Kerja Sebagai Variabel Intrvening (Studi Kasus Pada KUD " KOTA Pati. Jurnal Of Management, Vol.2 No.2 hal 1-13

Sugiyono. 2016. Metodologi Penelitian Kuantitatif, Kualitatif, dan R\&D.CV Alfabeta. Bandung 